NOTAS

\title{
A LA MEMORIA DE MILAGROS MIER
}

Kuthumi Palma*

$\mathrm{D}$ encontrar las palabras que puedan describir todo lo que Milagros Mier representó para mi formación; a través de las siguientes líneas intentaré transmitir 'algo' de todo lo que significó para las personas que tuvimos la oportunidad de conocerle.

Profesora, amiga, esposa, hermana, todas estas facetas las desempeñaba día con día. Yo tuve la oportunidad de conocerla como su alumno durante el primer semestre de mi carrera. No hay duda de que fue una maestra muy especial a la que admiré por la gran devoción que demostraba tener clase tras clase.

Nunca faltó ni llegó tarde a una de ellas; siempre se le veía convencida de lo que enseñaba y lo transmitía con un vigor sobresaliente.

* Estudiante de Ingeniería en Telemática, $2^{\circ}$ semestre. Llevó Ideas I con la Profesora Milagros.
Aún recuerdo mi primer día en la universidad, mi segunda clase, desde entonces se notó que era diferente; siempre exigente, quien quería estar ahí requeriría de un gran esfuerzo y dedicación; a cambio, el disfrute de una clase verdaderamente extraordinaria. En cada una, ella se entregaba al máximo por enseñamos la filosofía de un modo diferente; debo reconocer que antes de entrar al ITAM no me gustaba la filosofía en lo absoluto, sin embargo, fue Milagros Mier quien me hizo cambiar radicalmente mi punto de vista, al grado de convertirse en una de mis materias predilectas. Realmente deseaba entrar a cada sesión, nunca falté a una de éstas. De hecho, me acuerdo de aquellos primeros días cuando todavía le era difícil pronunciar mi nombre, nos reíamos vez tras vez hasta que finalmente se lo aprendió. También, desde aquellos días se hicieron famosas algunas de 
NOTAS

sus frases como 'Ande usted', 'Platón es Platón’ y algunas otras más.

Además, no se limitaba a hablarnos del material programado, en varias ocasiones se valía de éste para inculcar en nosotros valores como la tolerancia, la igualdad, la justicia, indispensables para hacer de esta sociedad algo mucho mejor.

¿Sus exámenes? Nos daban un poco de miedo y nos tomaba bastante tiempo prepararnos para ellos, pero se sentía una gran satisfacción cuando nos los regresaba y notábamos que habíamos hecho un buen examen. Ahora me vino a la mente una ocasión en la que para contestar un examen escribí seis páginas, al entregarlo y despedirme me dijo: 'Adiós Biblia en verso’; desde esa ocasión solía decirme así.

Sin duda, fue una maestra excepcional, siempre dispuesta a atender a sus alumnos e intentando formar en ellos una mentalidad diferente con miras a construir una mejor vida, un mejor mundo.

No hay palabras para describir mi agradecimiento por todo en lo que me ayudó tenerla como maestra; fue clave que en mi primer semestre haya tenido el honor de conocerla: me exhortó a continuar y a ver que no es fácil el camino, pero que con constancia y voluntad se puede recorrer.
¡Gracias Maestra! ¡Gracias por todo! Descanse en paz, Milagros Mier. 